\title{
THE ANALYSIS OF FACTORS RELATED TO CREATIVITY IN THE SAMPLE OF PHYSICAL EDUCATION TEACHERS
}

\author{
Dalia Lapėniene் $\dot{1}^{1}$ Audronė Dumčiene் $\dot{1}^{1}$ Tomas Lapėnas ${ }^{2}$ \\ Lithuanian academy of Physical Education ${ }^{1}$, Kaunas, Lithuania \\ Joint Stock Company TS Construction', Kaunas, Lithuania
}

\begin{abstract}
Research background and hypothesis. There are many obstacles for creativity in physical education teachers' work but majority of physical education teachers tend to work creatively so it is worthwhile to explore which variables predict creativity. The hypothesis of the study: Personal factors are more important for physical education teachers' creativity in comparison to social factors.

Research aim was to identify individual and social factors, predicting creativity in the sample of physical education teachers.

Research methods. Quantitative study. The questionnaire survey was used to establish the level of creativity, creative self-efficacy, motivation, emotions and the microclimate characteristics. The sample involved 120 physical education teachers.

Research results. Creativity was predicted by self-efficacy and intrinsic process motivation. Extrinsic motivation inhibited creativity in physical education teachers' work. Supervisory encouragement for creativity has the only social factor facilitating creativity.

Discussion and conclusions. The obtained data confirmed interrelation between creativity and self-efficacy and validated results obtained by D. F. De Moulin (1993). Intrinsic process motivation also predicts creativity. It is in agreement with Y. Ommundsen and S. Eikanger Kvalo's (2007) results. Extrinsic motivation has negative impact towards creativity. It is possible that teachers motivated intrinsically create task-involving motivational climate which leads to competitiveness (Ommundsen, Eikanger Kvalo, 2007). Supervisory encouragement is the only social variable predicting teachers' creativity. The data revealed that supervisors' behavior was more important than that of colleagues (Laker et al., 2008; Blankenship, Coleman, 2009).
\end{abstract}

Keywords: creativity, personal and social factors.

\section{INTRODUCTION}

$\mathrm{R}$ elevance. Creativity is defined as essential competence in contemporary knowledge society, that is why educational system seeks to develop creativity in youth. Teachers' creativity as an important factor of educational progress is mentioned in European and Lithuanian educational documents. Creative teaching is defined as teachers' ability to make educational process more interesting using students' emotions, imagination and other abilities related to creativity
(NACCCE, 1999). In educational literature it is defined as effective teaching because it develops students' creative abilities and intrinsic interest in the curriculum (Jeffrey, Craft, 2004).

Creativity is important, because it is a good way to make the curriculum interesting and it enhances students' efforts in learning. The ways of students' engagement are determined by the goals of different subjects. Creativity is different in various subjects, but it has the same essence, 
i. e. teachers seek to solve professional issues innovatively and to motivate students.

Manifestations of physical education teachers' creativity receive more and more interest in scientific literature. During the lessons, creative physical education teachers organize educational activities to facilitate students' desire for movement, freedom to experiment and search for new movements or game strategies. R. Nicholson (1999) indicated fundamental teachers' competencies which lead to the creativity: ability to convey subject knowledge, ability to stimulate students' curiosity and desire to study, ability to engage or enhance intrinsic motivation, ability to encourage students to risk, ability to express trust in students' abilities, ability to create environment for choice and discovery, and ability to develop students' self-control skills.

Considering the importance of creativity in physical education teachers' work, it is important to emphasize the challenges for creativity. Macro level challenges come from social environment: general attitudes toward health and activity in nowadays society. Mezo level factors are associated with schools' institutional barriers. Micro level can be defined as personal and interpersonal factors or lack of encouragement.

Appreciating barriers for physical education teachers' creativity, it is important to emphasize personal and social factors, facilitating creativity in the workplace. Literature reveals that creativity comes from personality and unrolls in social environment.

Considering personal factors facilitating creativity, it is worthwhile to start from selfefficacy. According to D. F. De Moulin (1993), selfefficacy level differentiates effective teachers from less effective. Self-efficacy is defined as person's trust in his/her ability to work successfully in the selected field. Self-efficacy is essential in the environment, where persons hold responsibility for the outcomes and are aware of the meaning of their job.

Self-efficacy is correlated with work motivation. Both self-efficacy and motivation derive from self concept. N. H. Leonard et al. (1999) proposed theory of work motivation explaining the influence of self-concept. Traditionally creativity is correlated with intrinsic and extrinsic motivation (Amabile et al., 1996). Extrinsic motivation is defined as "the motivation to work primarily in response to something apart from the work itself, such as reward or recognition or the dictates of other people" (Amabile et al., 1994, p. 950). Intrinsic motivation is "the motivation to engage in work primarily for its own sake, because the work itself is interesting, engaging, or in some way satisfying" (Amabile et al., 1994, 950 p.). N. H. Leonard et al. (1999) sophisticated the concepts of work motivation and introduced five sources of motivation: instrumental, intrinsic process, goal internalization, extrinsic and intrinsic self-concept motivation. Instrumental motivation can be defined as engagement expecting tangible outcomes, such as pay, praise, etc. Intrinsic process motivation can be defined as engagement because of fun and enjoyment, e. g. motivation comes from the work itself and feels rewarded simply by performing the task. Goal internalization motivation can be defined as engagement because of congruence between behavior and ones' value system. Intrinsic self-concept motivation can be defined as engagement because of inner-directedness, e. g. an individual behaves in a certain way because of internal standard which becomes the basis for the ideal self. Extrinsic self-concept motivation is primary other-directed, e. g. individual attempts to meet the expectation of other people (Leonard et al., 1999). According to the definition of creativity and the studies in the area of social psychology of creativity intrinsic process motivation is considered as facilitating creativity, and instrumental/extrinsic motivation may be a barrier for creativity.

Intrinsic process motivation has much in common with positive emotions. According to M. Chang (2010), teachers often encounter stress, emotional exhaustion, and burnout at their job. Scientists distinguish five emotions which have the most disruptive effect: anxiety, anger, shame, guilt, and sadness. Teachers' emotions are interrelated with their work motivation. Intrinsic process motivation determines persons' involvement and efforts (Ommundsen, Eikanger Kvalo, 2007). Persistence and seeking to participate in the social life of the school are named as essential factors contributing to successful adaptation of novice physical education teachers (Blankenship, Coleman, 2009). Intrinsic process motivation may serve as a protective factor determining teachers' resilience to job related stress and negative emotions.

In the scientific literature social environment is considered as a source of challenges for physical education teachers, but it also enhances teachers' creativity. Positive characteristics, such as school 
policy, colleagues and supervisors' support help to reduce the level of stress and obtain trust in collective ability to overcome obstacles (Klassen, 2010). According to A. Laker et al. (2008) supervisory support and encouragement are the main factors contributing to novice teachers' educational and professional development. Supervisory encouragement manifests as a supply of sufficient recourses, settlement of standards for high quality and consultation when teachers face obstacles in their everyday work.

Physical education teachers' creativity is linked to individual and social factors. The estimation of these factors discloses possibilities for the enhancement of teachers' creativity in the work place.

The object of the study was relations of creative self-efficacy, motivation, emotions and organizational climate factors to physical education teachers' creativity.

The aim of the study was to identify individual and social factors, predicting creativity in the sample of physical education teachers.

Hypothesis: Personal factors are more important for physical education teachers' creativity in comparison to social factors.

\section{RESEARCH METHODS}

Participants. One hundred twenty physical education teachers participated in the study. All participants worked in various schools of Kaunas region, Lithuania. The mean age of the participants was 42 years. $32.4 \%$ of participants were men, and $66.7 \%$ were woman. The mean year of work experience in the sample was 19 years. $19.1 \%$ of the participants were teachers, $48.5 \%$ - senior teachers, and $32.4 \%$ - supervisor teachers. None of these characteristics had statistically significant impact for the ratings of the scales.

Procedure. Participants were surveyed during the seminars of professional development after obtaining permission from relevant institutions and from participants. The questionnaires were administered by one of the authors who encouraged participants to answer truthfully and to ask if they had difficulty in understanding instructions or items in the questionnaire. It took teachers approximately 30 minutes to complete the questionnaire.

Instrument. The anonymous questionnaire was used. The questionnaire was composed of three parts.
The first part was designed to measure perceived creativity in the domain of teaching physical education. It was designed in accordance with the work of S. M. Farmer et al. (2003). The scale was adapted according secondary school teachers' work characteristics. The scale consisted of ten items. Each item was rated on a 5-point scale ranging from 1 (not at all true to me) to 5 (absolutely true to me). Example of the statement: "I constantly try to make something differently".

The second part of the questionnaire was designed to measure individual factors, which theoretically correlated with creativity: creative self-efficacy, positive and negative emotions, goal internalization motivation, intrinsic process motivation, and extrinsic motivation. Creative selfefficacy scale was designed in accordance with the work of P. Tierney and S. M. Farmer (2004). The scale consisted of seven items. Each item was rated on a 5-point scale, ranging from 1 (not at all true to me) to 5 (absolutely true to me). Example of the statement: "I trust my abilities to solve problems creatively". Positive and negative emotion scale consisted of ten primary emotions. Participants were asked to rate the frequency of the emotions on the scale ranging from 1 (never) to 5 (always). Work motivation scales were designed according to the work of N. H. Leonard et al. (1999). Three types of work motivation were measured using eighteen items. Each item was rated on a 5-point scale, ranging from 1 (it is not important to me) to 5 (it is very important to me). The example of the statement in goal internalization motivation scale: "Professional expertise is a value to me". The example of the statement in intrinsic process motivation scales: "Working process for me is more important than the pay for it". The example of the statement in extrinsic motivation scales "I work driven by the desire to get higher pay".

The third part of the questionnaire was designed to measure social factors which theoretically correlated with creativity: work group support, co-worker expectations towards creativity, organizational encouragement, supervisory encouragement, sufficient resources and creativity encouragement. Work group support scale was designed in accordance with the work of T. M. Amabile et al. (1996). The scale consisted of seven items indicating behavior of co-workers. Each item was rated on a 5-point scale ranging from 1 (rarely) to 5 (always). The example of the statement: "My colleagues are 
able to resolve conflicts constructively". The coworker expectation towards creativity scale was designed in accordance with the work of S. M. Farmer et al. (2003). The scale consisted of six items indicating behavior of co-workers. Each item was rated on a 5-point scale ranging from 1 (rarely) to 5 (always). The example of the statement: "My colleagues expect from me important insights, when we try to find solutions to various problems". Organizational encouragement scale was designed in accordance with the work of G. R. Oldham and A. Cummings (1996). The scale consisted of seven items, indicating behavior of supervisor. Each item was rated on a 5-point scale ranging from 1 (rarely) to 5 (always). The example of the statement: "My supervisor publicly recognizes the efforts to work creatively". Supervisory encouragement scale was designed in accordance with the work of T. M. Amabile et al. (1996). The scale consisted of four items indicating behavior of supervisor. Each item was rated on a 5-point scale ranging from 1 (rarely) to 5 (always). The example of the statement: "My supervisor emphasizes the importance of cooperation with colleagues". Sufficient resources scale was designed in accordance with the work of T. M. Amabile et al. (1996). The scale consisted of four items indicating sufficiency of resources for creative work. Each item was rated on a 5 -point scale ranging from 1 (rarely) to 5 (always). The example of the statement: "My supervisor provides the necessary tools to work". Creativity encouragement scale was designed in accordance with the work of G. R. Oldham and A. Cummings (1996). The scale consisted of four items indicating behavior of supervisor. Each item was rated on a 5 -point scale ranging from 1 (rarely) to 5 (always). The example of the statement: "My supervisor encourages seeking for innovative goals".

Analysis. The data was processed using SPSS 16 for Windows.

The reliability of the scales was estimated by calculating Cronbach's alpha coefficients. Hierarchical regression analysis was employed to estimate prognostic values for independent variables.

\section{RESEARCH RESULTS}

The reliability of the scales was checked by calculating Cronbach's alpha coefficients. The data are presented in Table 1.

The analysis confirmed the reliability of the scales which was used for further analysis.
Table 1. Chronbach's alpha coefficients of the scales used in the study

\begin{tabular}{|r|l|c|}
\hline \multicolumn{2}{|c|}{ Scales } & $\begin{array}{c}\text { Cronbach's } \\
\text { alpha } \\
\text { coefficient value }\end{array}$ \\
\hline 1. & Perceived creativity & 0.792 \\
\hline 2. & Creative self-efficacy & 0.774 \\
\hline 3. & Negative emotions & 0.603 \\
\hline 4. & Positive emotions & 0.701 \\
\hline 5. & Goal internalization motivation & 0.791 \\
\hline 6. & Extrinsic motivation & 0.835 \\
\hline 7. & Intrinsic process motivation & 0.612 \\
\hline 8. & Work group support & 0.886 \\
\hline 9. & Co-worker expectations towards creativity & 0.829 \\
\hline 10. & Organizational encouragement & 0.902 \\
\hline 11. & Supervisory encouragement & 0.847 \\
\hline 12. & Sufficient resources & 0.833 \\
\hline 13. & Creativity encouragement & 0.626 \\
\hline & & \\
\hline
\end{tabular}

Hierarchical regression analysis was used to identify prognostic values for independent variables (creative self-efficacy, negative emotions, positive emotions, goal internalization motivation, extrinsic motivation, intrinsic process motivation, work group support, co-worker expectations towards creativity, organizational encouragement, supervisory encouragement, sufficient resources, and creativity encouragement). The data are presented in Table 2.

The results indicate that there are three factors statistically significantly predicting creativity in a positive way. These are creative self-efficacy, intrinsic process motivation and supervisory encouragement. Extrinsic motivation statistically significantly predicts creativity in the negative way, i. e. inhibits creativity of physical education teachers. Other factors have no statistically significant impact on physical education teachers' creativity.

\section{DISCUSSION}

The obtained data confirmed interrelation between creativity and self-efficacy. Creative self-efficacy has the highest predictive values to creativity in the sample of physical education teachers. It validates the results of D. F. De Moulin's (1993) study and allows drawing the conclusion that teachers who trust their abilities choose to work creatively. The results are in accordance with findings in the scientific literature. The person's high self-efficacy is manifested as positive attitude towards the self and duties (De Moulin, 1993). 


\begin{tabular}{|r|l|c|c|c|c|}
\hline \multicolumn{2}{|c|}{ Independent variables } & $1^{\text {st }}$ model & $2^{\text {nd }}$ model & $3^{\text {rd }}$ model & $4^{\text {th }}$ model \\
\hline 1. & Positive emotions & $2.68^{*}$ & $2.30^{*}$ & $2.22^{*}$ & -0.45 \\
\hline 2. & Negative emotions & -1.01 & -1.66 & -1.37 & -1.25 \\
\hline 3. & Organizational encouragement & & -1.87 & -1.67 & -0.42 \\
\hline 4. & Supervisory encouragement & & 0.24 & 0.32 & 0.27 \\
\hline 5. & Sufficient resources & & -1.47 & -1.34 & -0.81 \\
\hline 6. & Creativity encouragement & & $3.54^{* *}$ & $3.28^{* *}$ & $3.16^{* *}$ \\
\hline 7. & Work group support & & -0.27 & 0.51 \\
\hline 8. & Co-worker expectations & & 0.38 & -0.94 \\
\hline 9. & Extrinsic motivation & & & 0.56 & $-2.24^{*}$ \\
\hline 10. & Creative self-efficacy & & & $3.74^{* *}$ \\
\hline 11. & Goal internalization motivation & & & & 0.36 \\
\hline 12. & Intrinsic process motivation & & & 0.50 & 0.77 \\
\hline & R & & & & \\
\hline
\end{tabular}

Table 2. Main results of hierarchical regression analysis: $t$ values and statistical significance

There is positive correlation between teachers' self-efficacy and attitudes towards students, their accomplishments, job satisfaction, attitudes towards professional development, creativity in the workplace (De Moulin, 1993), application of innovative teaching tools, teaching style diversity, enthusiasm, openness to new ideas, and variety of teaching methods (Stephanou, Tsapakidou, 2007). It is not surprising that physical education teachers who demonstrate high creative self-efficacy indicate higher levels of professional creativity.

Intrinsic process motivation predicts creativity in the sample of physical education teachers. These data prove predictions that intrinsic motivation enhances creativity, because it is interrelated with interest, activity, positive emotions, positive attitudes towards the work (Ommundsen, Eikanger Kvalo, 2007). On the other hand, extrinsic motivation has negative impact towards creativity. The data of the study encourage considering the concept of motivational climate.

Creative teaching is manifested as teachers' ability to create task-involving motivational climate. Foreign studies disclose that students' motivation and efforts are determined by the motivational climate in a lesson (Liukkonene et al., 2010). According to the way how students define achievements, motivational climate can be characterized as task-involving or egoinvolving. Ego-involving motivational climate is characterized as emphasizing outcomes and social comparison of students according to their results.
This environment enhances extrinsic motivation and students' anxiety due to their results, but it suppresses interest and joy of movement (Duda, Whitehead, 1998). The results of teachers' ability to create task-involving motivational climate is that students learn to associate activity with personal development and to consider participation, activity and efforts as the main outcomes of physical education. According to J. Liukkonene et al. (2010), task-involving motivational climate is preferred because students learn such skills as self-evaluation and goal establishment. Behavior of physical education teachers determines the kind of motivational climate during the educational activities. The application of cooperative learning methods, focusing on positive roles of students, and concernin the personal development of every student are correlated with task-oriented motivational climate (Newton, Duda, 1993). Fostering students' responsibility for their productivity (Papaioannou, 1994) and joy, satisfaction, intrinsic interest, efforts during the lessons is also related to task involving motivational climate (Liukkonene et al., 2010). On the other hand, the teacher who punishes students for their mistakes promotes interpersonal competition atmosphere in the class (Newton, Duda, 1993), takes personal responsibility for learning outcomes (Papaioannou, 1994), creates ego-involving motivational climate. This kind of climate might be characterized as concern about personal image, pressure, anxiety, the reluctance to participate (Liukkonene et al., 2010). According 
to Y. Ommundsen and S. Eikanger Kvalo (2007), lesson planning, evaluation system and sharing the responsibility for outcomes are the key elements of a lesson which determine motivational climate in the class. It is purposeful to draw the conclusion that there are two main ways to organize physical education lessons: to create ego-involving climate characterized as competitive or to create taskinvolving climate, characterized as creativity enhancing. Physical education teachers personally motivated by intrinsic process motivation tend to create task - involving climate and facilitate students' creativity. It is also possible that physical education teachers personally motivated by extrinsic motivation tend to create ego - involving climate and encourage pupils' competitiveness. The data confirmed that extrinsic motivation was opposite to teaching creatively (Ommundsen, Eikanger Kvalo, 2007).

Supervisory encouragement is the only social characteristics predicting physical education teachers' creativity. It confirms the data of other research indicating the importance of supervisory encouragement for professional development. The data allow drawing the conclusion that supervisors' behavior is more important than that of colleagues (Laker et al., 2008; Blankenship, Coleman, 2009). Three other characteristics analyzed in the current study have no statistically significant impact. It contradicts to the results of scientists who emphasize the role of resources (McCaughtry et al., 2006), creativity encouragement (Laker et al., 2008; Klasser, 2010), and organizational encouragement (Blankenship, Coleman, 2009). It is possible that social factors are not favorable for creative physical education teaching.

Scientists emphasize that teachers face the challenges of negative social environment during the work and it can be an important reason why the majority of them do not evaluate organizational encouragement as favorable for creativity. Considering global issues K. Hardman (2008) concludes that nowadays there are three main social challenges for physical education teachers. It is the cult of slim body between youth, children obesity and adolescents' physical passiveness. K. B. Bevans et al. (2010) emphasize that physical passiveness as well as disengagement in sports is the issue of a whole family, not only an adolescent. According to V. Rakauskienè and L. Kardelienè (2009), students' health related behavior is determined by the health related knowledge and understanding about the importance of physical activity. Unfortunately, it has been stated that students' physical activity nowadays is the means to improve body shape, but not to improve their general culture (Jankauskiene, 2008). The scientists' state that the need for physical self development as well as positive attitude towards physical education and healthy life style is not emphasized enough at schools (Dumčienè et al., 2007). It has been estimated that teachers' creativity during physical education lessons might change students' negative attitude towards physical activity (Rakauskiené, Kardelienè, 2009).

Physical education teachers face many dayto-day work barriers in the workplace. According to K. DeCorby et al. (2005), one of the most important problems derives from the attitudes that physical education discipline is thought to be not essential in the curriculum. The social reality, such as a decrease of financial resources, demands to give priority for the so-called essential curriculum (math, languages, etc.). The decrease of resources for physical education results in the negative attitude of students and their families towards the importance of physical education in comparison to other disciplines (DeCorby et al., 2005; Hardman, 2008; Bevans et al., 2010), the lack of teachers professional competence (DeCorby et al., 2005; McCaughtry et al., 2006; Hardman, 2008), the lack of essential resources and tools (Hardman, 2008; McCaughtry et al., 2006; Bevans et al., 2010), the increase in class size because of retrenchment (DeCorby et al., 2005; McCaughtry et al., 2006), the emphasis of teachers' responsibility for the outcomes and not attaching them to students' parents (Boyle et al., 2008) - these are the main barriers for creativity of physical education teachers.

These negative factors inhibit physical education teachers' creativity, efforts, motivation and trust in their competence in the micro level. The study of B. T. Blankenship and M. M. Coleman (2009) disclosed that the lack of possibilities and tools as well as negative image of the subject and the lack of respect from the students, conditioned the attitudes to quit the job in the sample of the novice physical education teachers. The teachers of physical education are often marginalized in the workplace. Such condition inhibits the development of professional mastery and creativity. That is the reason why physical education teachers do not see organizational encouragement as resource for creativity. On the other hand supervisory efforts to 
facilitate creativity are appreciated - it makes the difference. Supervisory encouragement helps to overcome the majority of micro level barriers for creativity that physical education teachers face in the job.

Other possible reason of supervisory encouragement importance is the style of leadership covered by the concept. Supervisory encouragement manifests as supervisors' ability to communicate and give feedback in a positive and constructive way, to express clear expectations about the quality of professional activity and the place of creativity in it. According to Y. Ommundsen and S. Eikanger Kvalo (2007), the teacher who creates task-oriented motivational climate has ability to give positive feedback, emphasizes efforts and progress, praises pupils who make visible progress, emphasizes the need for development, clearly defines the goals of learning, lets the pupils choose the means for learning. Supervisory encouragement involves similar kinds of behavior. It is possible that creativity encouraging managers are personally motivated by intrinsic process motivation and are able to create task-involving and creativity facilitating climate in the teachers' teams. These kinds of professional teams may be key factor in overcoming institutional barriers for creativity.

The role of the emotions in teachers' work is discussed in scientific literature emphasizing its impact to teaching methods and effectiveness (Chang, 2010; Klassen, 2010). The analysis did not confirm the predictive influence of emotions to creativity. The same can be said about the age of participants. There are some predictions that work experience increases with the age, so it is an important variable influencing teachers' mastery and creativity (De Moulin, 1993; Zeng et al., 2010).
The novice teachers are considered to be most sensitive for the barriers to professional mastery (Laker et al., 2008; Gurbuzturk, Sad, 2009). The obtained data did not confirm the role of age to the creativity of physical education teachers.

\section{CONCLUSIONS AND PERSPECTIVES}

The barriers of physical education teachers' creativity are widely discussed in the current scientific literature. It is also important to analyze factors facilitating creativity in the domain of professional activity. The presented study disclosed that creative self-efficacy and intrinsic process motivation positively predicted creativity in the sample of physical education teachers. These individual characteristics mentioned above are of primary importance, but there is only one social characteristic, i. e. supervisory encouragement, which predicts creativity of physical education teachers.

The results encourage offering some ideas for further research. There are three possible directions of scientific explorations. First of all, further studies of creativity and human agency are needed because they might clarify interrelations between creativity and self-efficacy. The second area of interest is intermediate variables between creativity and motivation, e. g. positive emotions, self-regulation mechanisms, teaching style, motivational climate preference, etc. The last area of possible interest might be the role of leadership and management for physical education teachers' creativity: which leadership style is the most suitable for creative teachers and what psychological and managerial mechanisms determine it.

\section{REFERENCES}

Amabile, T. M., Conti, R., Coon, H., Lazenby, J., Herron, M. (1996). Assessing the Work Environment for Creativity. Academy of Management Journal, 39 (5), 1154-1184.

Amabile, T. M., Hill, K. G., Hennessey, B. A., Tighe, E. M. (1994). The work performance inventory: Assessing intrinsic and extrinsic motivational orientations. Journal of Personality and Social Psychology, 66 (5), 950-967.

Bevans, K. B., Fitzpatrick, L. A., Sanchez, B. M., Riley, A. W., Forrest, Ch. (2010). Physical education resources, class management, and student physical activity levels: A structure - process - outcome approach to evaluating physical education effectiveness. Journal of School Health, 80 (12), 573-580.

Blankenship, B. T., Coleman, M. M. (2009). An examination of "wash-out" and workplace conditions of beginning physical education teachers. Physical Education, 66 (2).

Boyle, S. E., Jones, L. G., Walters, S. J. (2008). Physical activity among adolescents and barriers to delivering 
physical education in Cornwall and Lancashire, UK: Qualitative study of heads of PE and heads of schools [2010 12 27]. BMC Public Health, 8 (273). Internet link: http:/www.biomedcentral.com/1471-2458/8/273/

Chang, M. (2010). An appraisal perspective of teacher burnout: Examining the emotional work of teachers. Educational Psychology Review, 21, 193-218.

DeCorby, K., Halas, J., Dixon, Sh., Wintrup, L., Janzen, H. (2005). Classroom teachers and the challenges of delivering quality physical education. Journal of Educational Research, 98 (4), 208-220.

Duda, J. L., Whitehead, J. (1998). Measurement of goal perspectives in the physical domain. In J. L. Duda (Ed.), Advances in Sport and Exercise Psychology Measurement (pp. 21-48). Morgantown, WV: Fitness Information Technology.

Dumčienè, A., Malinauskas, R., Sipavičienè, S., Klizas, Š . (2007). Moksleivių sveikatinimo per kūno kultūros pamokas aspektai. Sveikatos mokslai, 3, 393341.

Gurbuzturk, O., Sad, S. N. (2009). Student teachers' beliefs about teaching and their sense of self-efficacy: A descriptive and comparative analysis. Inonu University Journal of the Faculty of Education, 10(3), 201-226.

Farmer, S. M., Tierney, P., Kung-McIntyre, K. (2003). Employee creativity in Taiwan: An application of role identity theory. Academy of Management Journal, 46 (5), 618-630.

Hardman, K. (2008). Physical education in schools: A global perspective. Kinesiology, 40 (1), 5-28.

Jankauskienè, R. (2008). Lietuvos gyventojų fizinio aktyvumo skatinimo strategija: kūno kultūra ar kūno kultas? Medicina, 44 (5), 346-355.

Jeffrey, B., Craft, A. (2004). Teaching creatively and teaching for creativity: Distinctions and relationships. Educational Studies, 30 (1), 77-87.

Klassen, R. M. (2010). Teacher stress: The mediating role of collective efficacy believes. The Journal of Educational Research, 103, 342-350.

Laker, A., Craig Laker, J., Lea, G. (2008). Sources of support for pre-service teachers during school experience. Mentoring \& Tutoring: Partnership in Learning, 16 (2), 125-140.

Leonard, N. H., Beauvais, L. L., Scholl, R. W. (1999). Work motivation: The incorporation of self-conceptbased processes. Human Relations, 52, 969-998.
Liukkonene, J., Barkoukis, V., Watt, A., Jaakkola, T. (2010). Motivational climate and students' emotional experiences and effort in physical education. Journal of Educational Research, 103, 295-308.

McCaughtry, N., Martin, J., Hodges Kulinna, P., Cothran, D. (2006). What makes teacher professional development work? The influence of instructorial resources on change in physical education. Journal of In-service Education, 32 (2), 221-235.

De Moulin, D. F. (1993). Re-conceptualizing the selfefficacy paradigm analysis of an eight-year study. Education, 114 (2), 167-199.

NACCCE. (1999). All our Futures: Creativity, Culture and Education. London: DfEE.

Newton, M., Duda, J. L. (1993). The relationship of task and ego orientation to performance: Cognitive content, affect, and attributions in bowling. Journal of Sport Behavior, 16, 209-220.

Nicholson, R. (1999). Enhancing creativity. In R. J. Sternberg, Handbook of Creativity (pp. 392-430). Cambridge: Cambridge University Press.

Oldham, G. R., Cummings, A. (1996). Employee creativity: Personal and contextual factors at work. Academy of Management Journal, 39, 607-634.

Ommundsen, Y., Eikanger Kvalo, S. (2007). Autonomymastery, supportive or performance focused? Different teacher behaviors and pupils' outcomes in physical education. Scandinavian Journal of Educational Research, 51 (4), 385-413.

Papaioannou, A. (1994). Development of a questionnaire to measure achievement orientations in physical education. Research Quarterly for Exercise and Sport, $65,11-20$.

Rakauskienè, V., Kardelienè, L. (2009). Metodinès ¡žvalgos apie edukacinị konsultavimą skatinant paauglių fizini aktyvumą. Pedagogika, 96, 83-87.

Stephanou, G., Tsapakidou, A. (2007). Teachers' teaching styles and self-efficacy in physical education. The International Journal of Learning, 14 (8), 1-12.

Tierney, P., Farmer, S. M. (2004). The pygmalion process and employee creativity. Journal of Management, 30 (3), 413-432.

Zeng, H. L., Leung, R. W., Hipscher, M. (2010). An examination of teaching behaviors and learning activities in physical education class settings taught by three different levels of teachers. Journal of Social Sciences, 6 (1), 18-28. 


\title{
KŪNO KULTŪROS MOKYTOJŲ KŪRYBINGUMO VEIKSNIŲ ANALIZE்
}

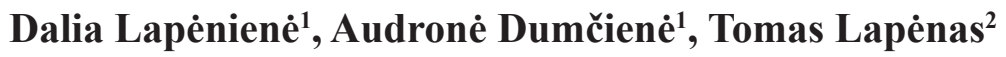 \\ Lietuvos kūno kultūros akademijal, Kaunas, Lietuva \\ Uždaroji akcine bendrove TS statyba'2, Kaunas, Lietuva
}

\section{SANTRAUKA}

Tyrimo pagrindimas ir hipotezè. Kūno kultūros mokytojai dirba kūrybingai nepaisydami daugelio kliūčių, todèl tikslinga tyrinèti, kokie asmenybiniai ir socialiniai veiksniai skatina mokytojus dirbti kūrybingai. Tyrimo hipotezè kūno kutūros mokytojų asmeninès savybės yra svarbesnès kūrybingumui, lyginant jas su socialiniais veiksniais.

Tikslas - nustatyti, kokie asmenybiniai ir socialiniai veiksniai prognozuoja kūno kultūros mokytojų kūrybinguma.

Metodai. Atliktas kiekybinis tyrimas naudojant anonimini klausimyną. 120 kūno kutltūros mokytojų isivertino kūrybingumą, kūrybini savaveiksmiškumą, motyvaciją, emocijas ir ịvertino darbovietės mikroklimato ypatumus.

Rezultatai. Kūrybingumą prognozuoja kūrybinis savaveiksmiškumas ir vidinè proceso motyvacija. Išorinè motyvacija slopina kūno kultūros mokytojų kūrybingumą. Vadovo drąsinimas kūrybingai dirbti yra vienintelis socialinis veiksnys, prognozuojantis kūrybingumą.

Aptarimas ir išvados. Gauti rezultatai patvirtina D. F. De Moulin (1993) tyrimo rezultatus ir pagrindžia savaveiksmiškumo svarbą kūrybingam mokytojo darbui. Nustatyta vidinès proceso motyvacijos prognoztinè itaka kūrybingumui. Šị ryši tikslinga aiškinti remiantis Y. Ommundsen ir S. Eikanger Kvalo (2007) teigimu, kad vidinè motyvacija neatsiejama nuo domėjimosi, aktyvumo, pozityvaus nusiteikimo, pasitenkinimo darbu, taigi ir kūrybingumo. Išorinè motyvacija neigiamai prognozuoja kūrybingumą. Tai galima paaiškinti tuo, kad išorinès motyvacijos vedami mokytojai formuoja ego orientuotą mikroklimatą ir skatina mokinių konkuravimą tarpusavyje (Ommundsen, Eikanger Kvalo, 2007). Vadovo drąsinimas yra vienintelis socialinis veiksnys, prognozuojantis kūno kultūros mokytojų kūrybingumą. Tai atitinka tyrimų duomenis, nurodančius, kad vadovas turi išskirtinių galimybiu skatinti kūrybines mokytojų iniciatyvas (Lake ir kt., 2008; Blankenship, Coleman, 2009).

Raktažodžiai: kūrybingumas, asmeniniai ir socialiniai veiksniai. 